University of Nebraska - Lincoln

DigitalCommons@University of Nebraska - Lincoln

$12-2003$

\title{
Analysis of Beef Producers' Risk Management Perceptions and Desire for Further Risk Management Education
}

\author{
David C. Hall \\ International Livestock Research Institute, Nairobi, Kenya \\ Thomas 0. Knight \\ Texas Tech University, tom.knight@ttu.edu \\ Keith H. Coble \\ Mississippi State University, keith.coble@msstate.edu \\ Alan E. Baquet \\ University of Nebraska-Lincoln, abaquet1@unl.edu \\ George F. Patrick \\ Purdue University, gpatrick@purdue.edu
}

Follow this and additional works at: https://digitalcommons.unl.edu/ageconfacpub

Part of the Agricultural and Resource Economics Commons

Hall, David C.; Knight, Thomas O.; Coble, Keith H.; Baquet, Alan E.; and Patrick, George F., "Analysis of Beef Producers' Risk Management Perceptions and Desire for Further Risk Management Education" (2003). Faculty Publications: Agricultural Economics. 75.

https://digitalcommons.unl.edu/ageconfacpub/75

This Article is brought to you for free and open access by the Agricultural Economics Department at DigitalCommons@University of Nebraska - Lincoln. It has been accepted for inclusion in Faculty Publications: Agricultural Economics by an authorized administrator of DigitalCommons@University of Nebraska - Lincoln. 
Published in Review of Agricultural Economics 25:2 (December 2003), pp. 430-448. Published on behalf of the Agricultural \& Applied Economics Association by Blackwell/John Wiley.

Used by permission. http://www.interscience.wiley.com/jpages/1058-7195

\title{
Analysis of Beef Producers' Risk Management Perceptions and Desire for Further Risk Management Education
}

\author{
David C. Hall, ${ }^{*}$ Thomas O. Knight, ${ }^{\dagger}$ Keith H. Coble, ${ }^{\ddagger}$ \\ Alan E. Baquet, $\$$ and George F. Patrick ॠ \\ * Animal Health Economist, International Livestock Research Institute, \\ Nairobi, Kenya \\ $\dagger$ Professor, Department of Agricultural Economics, Texas Tech University \\ $\ddagger$ Associate Professor, Department of Agricultural Economics, Mississippi \\ State University \\ $\S$ Associate Vice Chancellor, Institute of Agriculture and Natural \\ Resources, University of Nebraska-Lincoln \\ ๑ Professor, Department of Agricultural Economics, Purdue University
}

\begin{abstract}
Beef cattle producers were surveyed in Texas and Nebraska to investigate perceptions of sources of risk, the effectiveness of risk management strategies, and interest in further risk management education, particularly production risk, using probit analysis. Important decision variables identified are age, prior use of risk management tools, previous attendances of risk management education, and risk aversion. Severe drought and cattle price variability are identified as primary risk factors with potential to affect farm income. Extremely cold weather and disease are of less importance. Understocking pasture and storing hay are perceived most effective as risk management options.
\end{abstract}

T $t$ is often assumed that the management of risk is of paramount importance to 1 crop and livestock producers (Barry; Hardaker, Huirne, and Anderson). Yet, very little information is available on how livestock producers perceive and manage risk. In this paper, we present the results of a unique large-scale and broadly focused survey of beef producers' perceptions of risk and preferences for risk management. Information is offered on both production and, to a lesser extent, price risk. ${ }^{1}$ The results presented offer insight into questions such as what type 
of risk matters to beef producers, what tools do they perceive as being effective in managing those risks, and what sort of risk management education is of interest to them.

Many of the tools used by producers to manage risk are enhancements of basic management procedures that have been carefully planned to reduce the likelihood of an adverse event. Examples of these risk management tools include reducing pasture stocking pressure when a severe drought is expected, or strategically vaccinating calves against a disease that state veterinarians declare is increasing in severity. Institutionally sanctioned risk management programs and instruments, typically more highly structured and often provided by government, are available in a variety of forms for crop producers (Goodwin; Knight and Coble; Mahul; Patrick, Musser, and Eckman). Institutionally sanctioned production risk management tools specifically for beef cattle producers are much rarer.

Despite the apparent effectiveness of available livestock risk management tools (Rowan, White, and Conner), researchers have described lower preference for such tools by livestock producers compared with crop producers (Guyer; Lawrence and Wang; National Animal Health Monitoring System, 1997a; Schroeder et al.; Ward, Feuz, and Schroeder). One possible reason is differing levels of risk across livestock and crop enterprises. Alternately, lower preference may imply that livestock producers perceive these risk management tools to be somehow inadequate. As well, it may be that producers simply lack either the required training to use these tools effectively or the motivation to adopt a risk management tool, given their perception of its utility. The corollary to this observation is that a greater variety of structured risk management tools and training targeted to livestock producers may be required for a significant increase in usage to occur.

This may be possible with the introduction of the Agricultural Risk Protection Act of 2000 (U.S. Congress). In this legislation, the U.S. Federal Government has shown a strong commitment to funding the development of new risk management tools and educational programs. This includes up to a maximum of $\$ 75,000,000$ over 5 years for the development of pilot production risk management programs specifically directed towards livestock producers, including programs concerning reduced forage on rangeland caused by drought and livestock poisoning or disease. ${ }^{2}$ These programs are intended specifically for the mitigation of "income fluctuations inherent in the production and marketing of livestock, and protection for production losses" (section 132).

The development of new risk management instruments and educational programs for livestock producers is clearly considered important by Congress. Developing an effective risk management education program, however, requires understanding of the needs and interests of the audience. ${ }^{3}$ This study investigates the risk management actions and attitudes of beef cattle producers that may be helpful in predicting a role for future livestock risk management programs and instruments. From analysis of survey data in Texas and Nebraska, we provide insight to the risk preferences of beef cattle producers, their perceptions of the sources and importance of risk, and their perceived effectiveness of risk management strategies. Furthermore, we build on this information and model beef cattle producers' interest in obtaining additional information in the use of risk management tools. 


\section{Survey Procedures and Response}

To survey the risk management perceptions and preferences of beef cattle producers in Texas and Nebraska, a questionnaire survey was prepared by the project collaborators with the assistance of a survey specialist from the National Agricultural Statistical Service (NASS). To improve clarity of the questionnaire and minimize ambiguities and misinterpretations, outside experts were consulted, some of whom provided a review of the complete questionnaire. The survey was mailed to beef producers in April 2000 with an explanatory cover letter and a contact phone number for any questions about the questionnaire or survey. The letter also assured producers of their anonymity to the project collaborators and of the confidentiality of their individual responses.

Beef cattle operations identified to receive the questionnaire were selected from a NASS database using a stratified random sampling process. Stratification was based on NASS estimates of on-farm cattle numbers. Producers were classified in one of three strata of numbers of head of cattle: 50 to 499, 500 to 999, and 1,000 or more. Two weeks after the mail out, recipients were sent a reminder post card. An additional two weeks later, nonrespondents were mailed another copy of the questionnaire and cover letter. Questionnaires were mailed to 4,000 farms; 1,313 returned questionnaires contained complete information for the analysis, resulting in a useable response rate of $32.8 \%$.

\section{Results of the Questionnaire}

The following sections summarize the results of the beef producer questionnaire. First we present findings on beef producers' perceptions of the importance of broad sources of risk and the efficacy of alternative risk management tools in mitigating those risks. Then we delve further into perceptions of effectiveness of methods for managing specific risks including drought, cold weather and disease.

\section{Perception of Sources of Risk and Efficacy of Risk Management Tools}

Respondents were asked to rate sources of risk "in terms of their potential to affect your ranch/farm income," on a 5-point (low of 1 to high of 5) Likert scale (Gardner and Likert; Likert). Drought and cattle price variability were the greatest two concerns, with average responses of 4.4 and 4.3 respectively (Figure 1). The next cluster of sources of risk between 2.5 and 3.0 included extremely cold weather and disease. Finally, four sources of risk were rated between 2.0 and 2.5.

Clearly, producers have concerns about risk factors that can affect their income, such as drought and price variability. It is important to know how beef cattle producers perceive the potential of alternative risk management strategies to mitigate those risks. Respondents were presented with a list of nine risk management strategies and asked to "indicate how effective you believe each is in reducing your risk." From the responses summarized in Figure 2, it is distinctive that maintaining animal health clearly was viewed as the most effective strategy (mean of 4.2, and perhaps a paradoxical finding since disease ranked relatively low as a source of risk in Figure 1). Being a low-cost producer, maintaining financial or credit reserves, and off-farm investments were also considered important 
Likert scale ${ }^{1}$

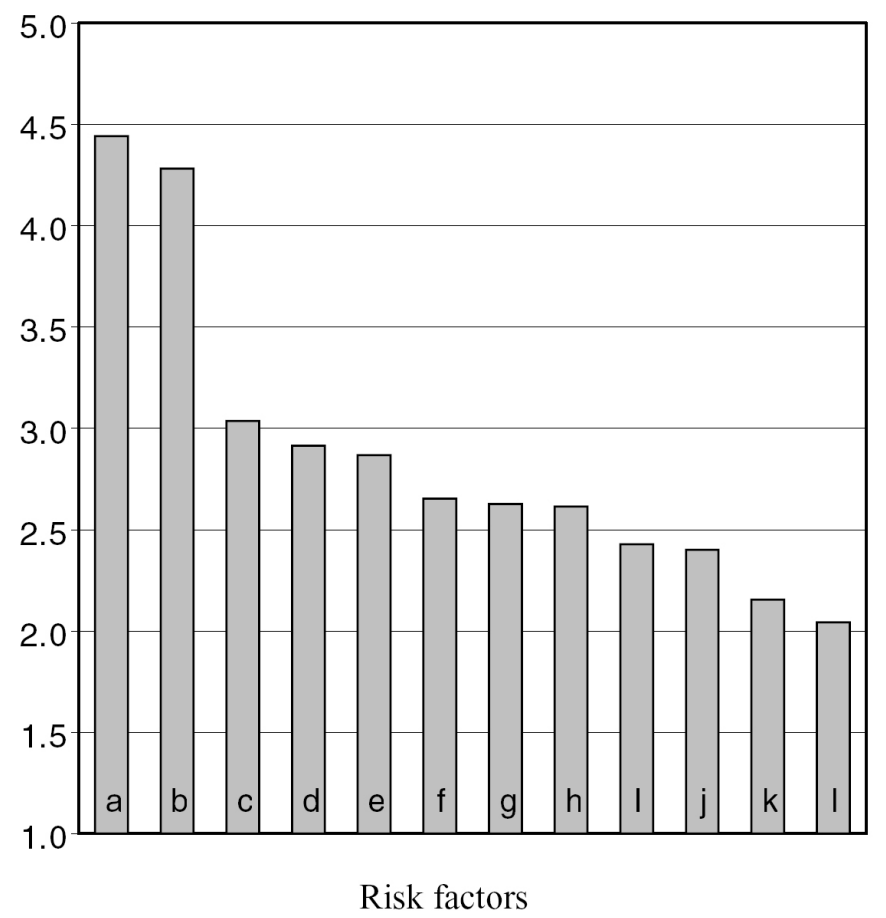

Figure 1. Beef producers' perceptions of potential of risk factors to affect ranch/farm income
a. Severe drought
b. Cattle price variability
g. Hay price variability
c. Variation in non-feed input prices
h. Disease
d. Changes in government
i. Land price variability environmental programs
e. Extremely cold weather
j. Variation in rented pasture availability
f. Changes in govt. farm programs
k. Labor availability
1. Labor price

${ }^{1}$ Likert scale $1-5$. See text for details.

practices (mean of 3.8, 3.6, and 3.6, respectively). Forward contracting and use of futures and options markets (mean of 2.2 and 2.0, respectively) were the two practices ranked least effective in reducing risk. This finding is paradoxical, considering beef producers' perception of the high potential for price variability to affect ranch or farm income (Figure 1).

\section{Perceived Effectiveness of Methods to Mitigate Drought, Cold, and Disease}

Producers perceived understocking pasture and storing a hay reserve as the most effective drought management strategies (mean of 4.1 and 4.0 respectively; Figure 3). Adjusting stocking rate, weaning calves early, and reducing the breeding 
Likert scale $^{1}$

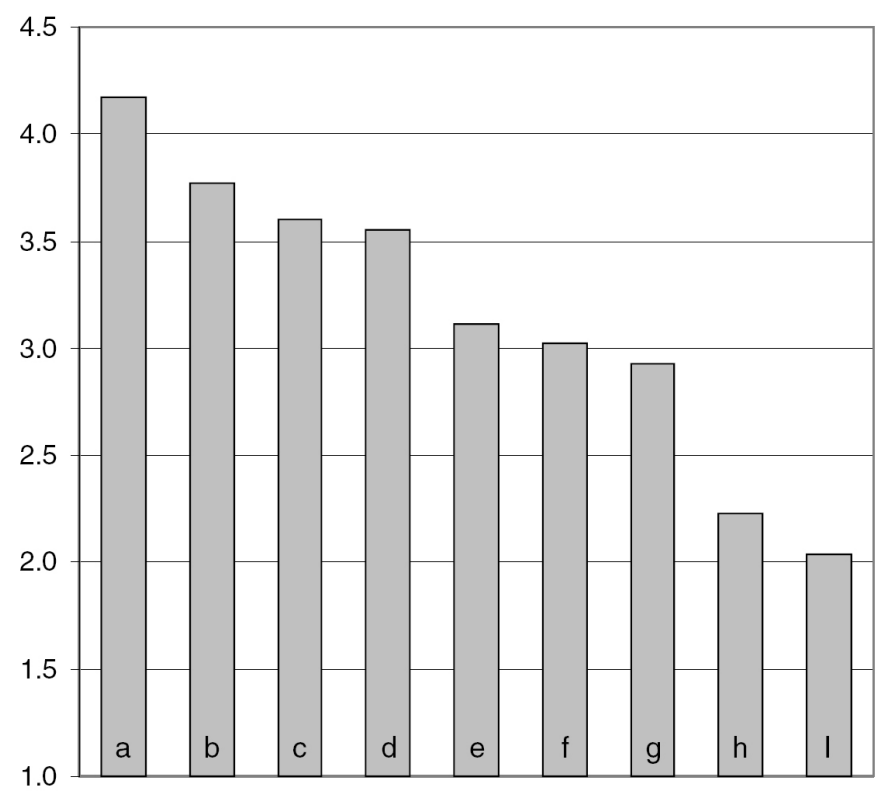

\section{Risk management strategies}

Figure 2. Beef producers' perceptions of potential of risk management strategies to affect ranch/farm income
a. Maintainin g animal health
b. Being a low cost producer
c. Maintaining financial/credit reserves
d. Off farm investments
e. Specializing in a phase of cattle production

f. Off farm employment

g. Diversifying ranch/ farm enterprises

h. Forward contracting

i. Futures and options

${ }^{1}$ Likert scale $1-5$. See text for details.

herd were ranked slightly less effective. Purchase of hay during drought (mean of 2.7) was ranked least effective. These findings reinforce what was described previously - that beef cattle producers perceive stocking rate as one of their most important risk management tools. Planning a forage reserve is often cited in extension literature as essential to a drought management strategy (Carpenter and Hart, Hart and Carpenter, White and Troxel), balancing herd size with nutrient availability and pasture sustainability. A large number of respondents (78.4\%) indicated they normally store hay to avoid a forage shortage during drought; the average reserve volume was 94 days worth of feed. ${ }^{4}$ It is possible that the purchase of hay was perceived as least effective in mitigating the effects of drought partly because of low availability and high prices during periods of drought. 


\section{Likert scale $^{1}$}

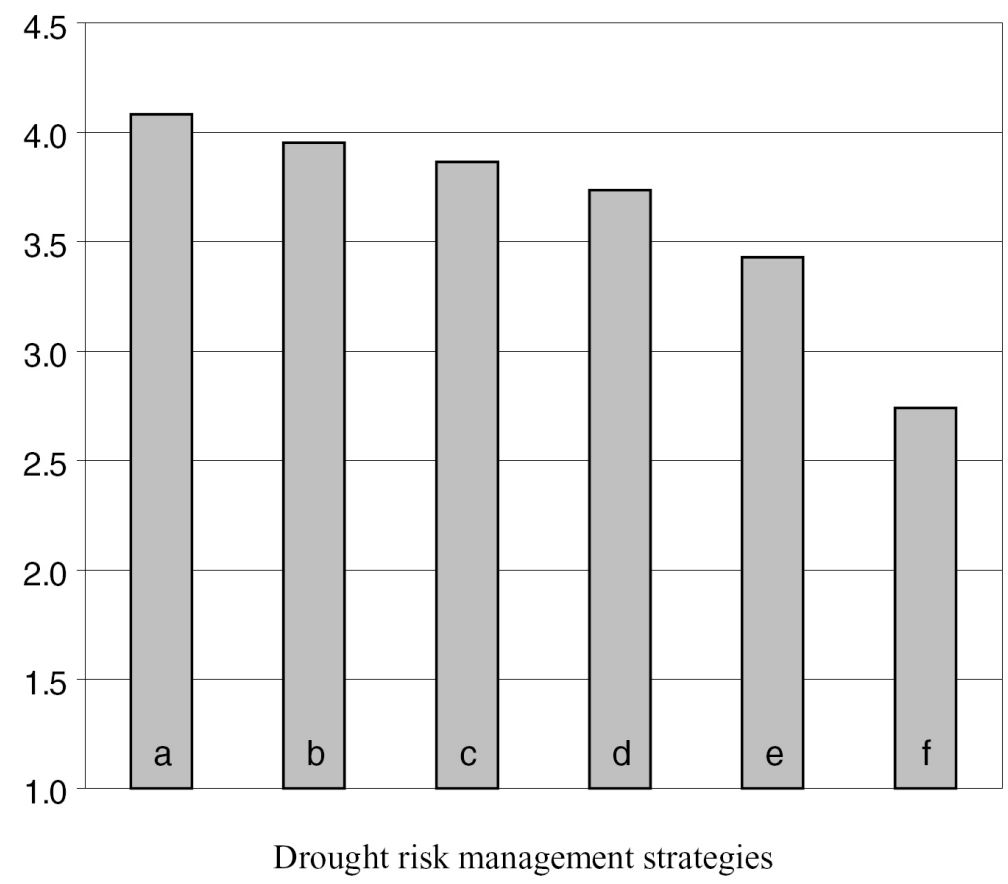

Figure 3. Beef producers' perceptions of the efficacy of drought risk management strategies
a. Under stocking pasture
b. Storing hay reserve
c. Adjusting stocking rate to current grazing capacity
d. Weaning calves early during drought
e. Reducing breeding herd during drought
f. Purchasing hay during drought

${ }^{1}$ Likert scale $1-5$. See text for details.

Cold weather is not a concern to beef producers in many parts of Texas, but it can be in North Texas and Nebraska. Thus, it is useful to know producers' perception of cold weather as a production risk factor. Those producers who lived in areas subject to extremely cold temperatures were asked to rate five cold weather risk management strategies (Figure 4). Storing hay or silage for heavy snowfalls (mean of 4.2) was judged most effective for mitigating the effects of cold weather, followed by checking cows daily (mean of 4.1). Again, hay storage is perceived as an important risk management strategy for beef cattle producers (no doubt, in some areas serving a dual purpose). Nearly all beef producers in areas subject to extremely cold temperatures $(92.5 \%)$ reported storing more hay than they expected to need to avoid a shortage. Checking cows daily and caring for cattle also 
Likert scale $^{1}$

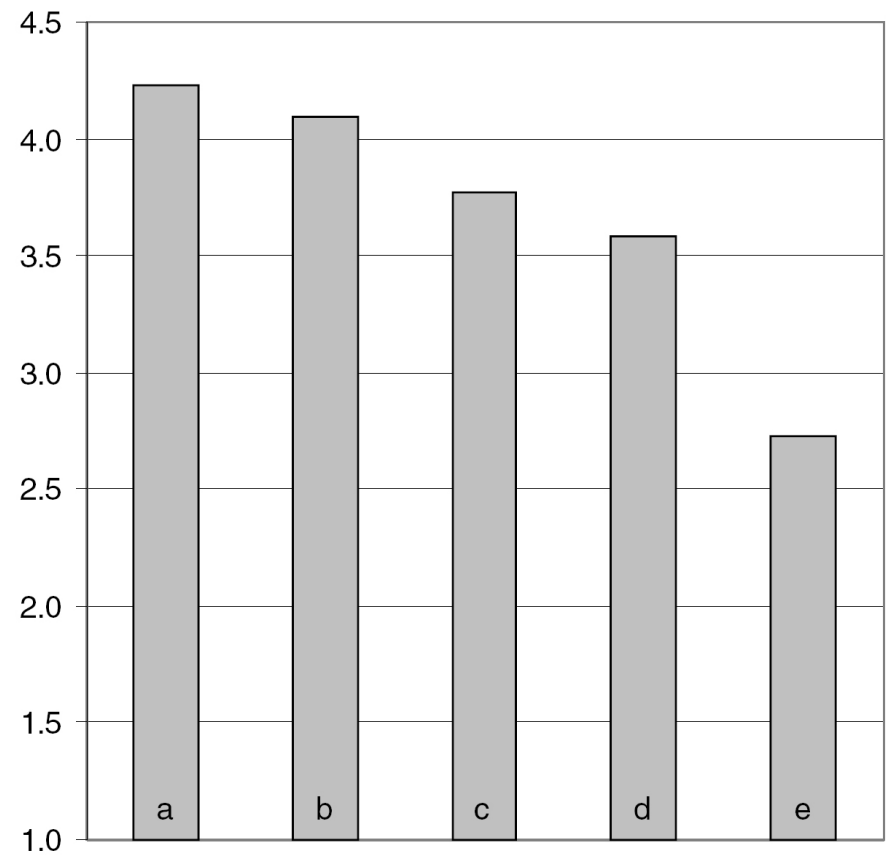

Cold weather risk management strategies

Figure 4. Beef producers' perceptions of the efficacy of cold weather risk management strategies

a. Storing hay/ silage for heavy snowfalls

b. Checking cows daily during cold weather

c. Being prepared to take care of chilled calves d. Calving first-calf heifers in an isolated pen or area

e. Calving all cows in an isolated pen or area

${ }^{1}$ Likert scale 1-5. See text for details.

were perceived as important, while calving all cows in an isolated pen was considerably less important (mean of 2.7). The latter result is likely due to the extra labor and time required for preparation and monitoring.

Questionnaire recipients were asked to rate several animal health management strategies, ranging from very basic (using a deworming treatment) to more advanced (having a protocol for the treatment of fever). Focusing on disease prevention ranked as the most important risk reducing health management practice (mean of 3.9; Figure 5), followed by inspecting the herd at least twice weekly (mean of 3.8).

The top two responses to this question could well be considered cornerstones of herd health management programs for beef cattle producers. One assumes the message of the herd veterinarian - to approach disease with prevention in mind (Radostits, Leslie, and Fetrow)-is reaching producers. However, veterinari- 
Likert scale $^{1}$

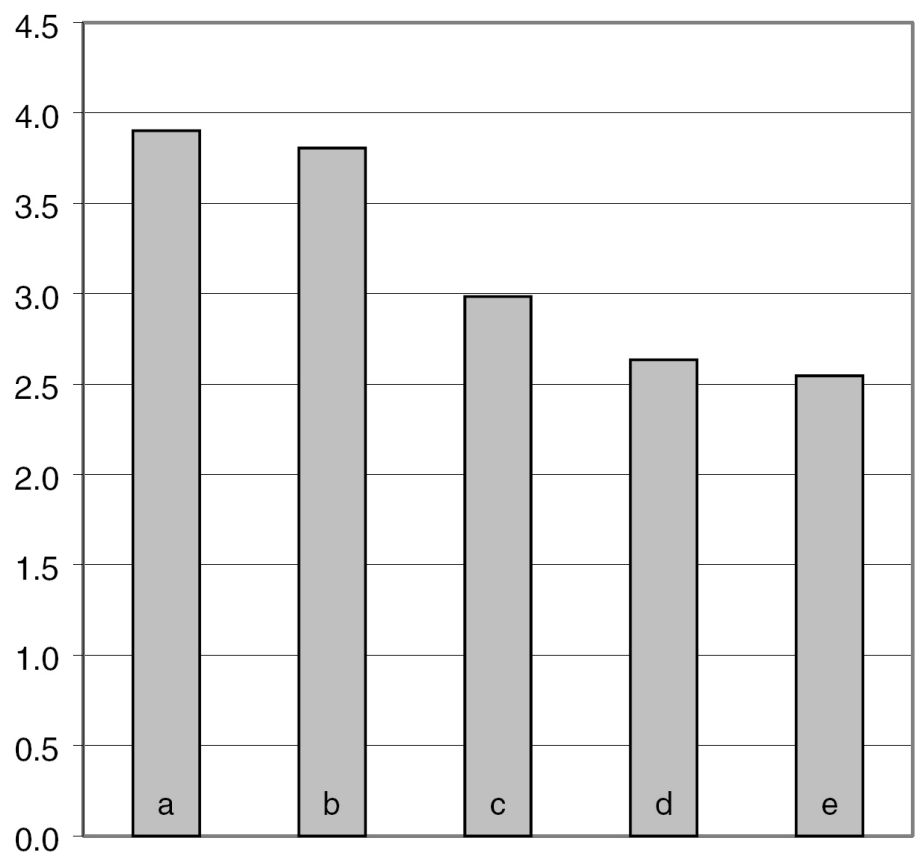

Animal health risk management strategies

Figure 5. Beef producers' perceptions of the efficacy of animal health risk management strategies
a. Focusing on disease prevention
d. Body condition scoring of cows
b. Inspecting herd at least twice weekly
e. Revaccinate calves as stockers
c. Consulting with a veterinarian

${ }^{1}$ Likert scale $1-5$. See text for details.

ans who promote herd health to beef producers will be disappointed to see that body condition scoring was not more important, because it is highly correlated with pregnancy rate. This low rating is likely due to cost of the facilities and labor required for routine body condition scoring. The lower value of revaccinating calves as stockers (whether keeping, buying, or selling) has been reported also by the National Animal Health Monitoring System (1997c, pp. 16-18), which found that two-thirds of producers did not revaccinate calves as stockers. The reason for this is unknown, but may be due to the perception that disease risk is too low to warrant revaccination.

\section{Risk Management Education Program Participation and Future Needs}

This section summarizes producers' interest in obtaining additional information or education in three risk management areas: alternative pricing mechanisms 


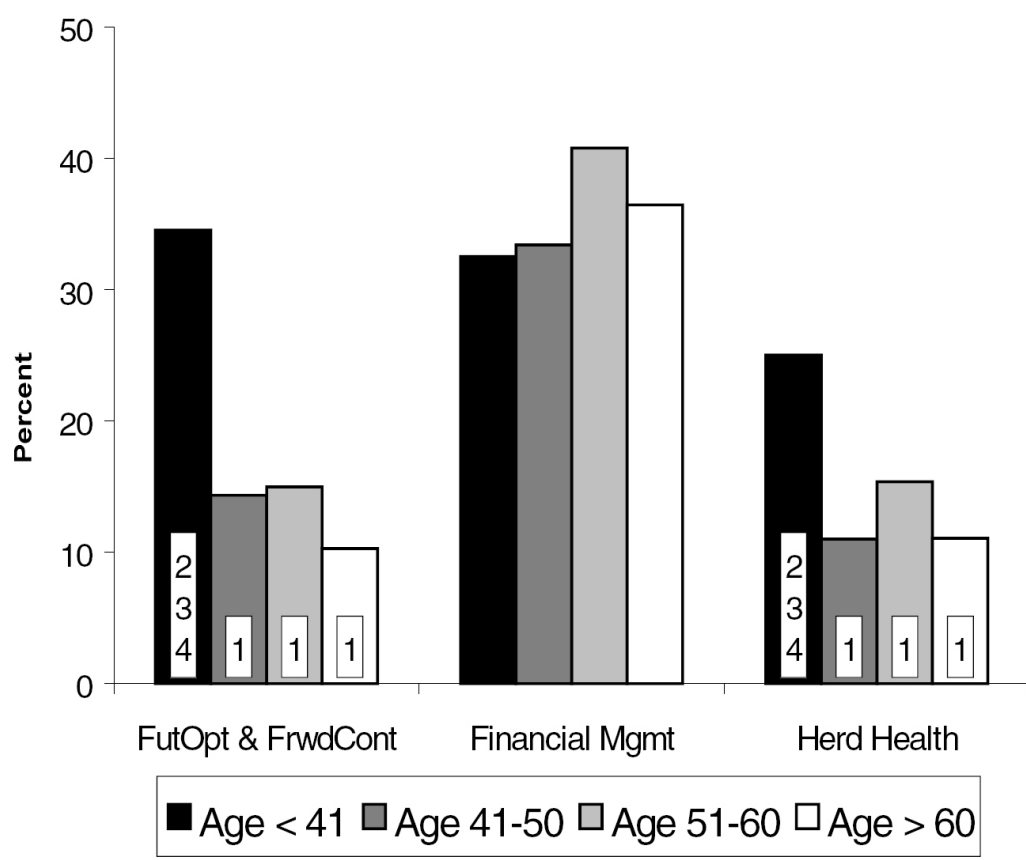

Figure 6. Beef producers' past attendance at educational seminars.

(Numbers in boxes represent pairwise relationships that are significant across the indicated strata)

(i.e., forward contracts and futures and options), financial management, and herd health management. As a basis for expected interest in future education, we first examine producers' interest in participating in risk management educational programs. In this analysis, producers are classified into four strata by age: less than 41 years, 41 to 50 years, 51 to 60 years, and 61 years and older.

To help explain our findings, we will refer to the Ben-Porath model of human capital investment, a model of the life-cycle evolution of human capital investment. Ben-Porath premised that human capital investment (education) is concentrated in the early third of one's life. Benefits from earlier education accrue over a longer period, encouraging workers to concentrate human capital investment in the earlier stages of working life. The model has been cited by Goodwin and Schroeder in evaluating educational program participation and factors affecting adoption of forward pricing methods among Kansas grain producers, and by Knight et al., who indicated that age and level of previous education were significant factors in determining crop producers' interest in risk management education.

Producers' average participation rates of prior risk management education (Figure 6) varied across age strata and subject matter from 10.3\% (strata 4, futures and options and forward contracting) to $40.8 \%$ (strata 3, financial management). Participation rates of training in use of alternative pricing mechanisms were significantly higher for participants 41 years of age and younger.

Participation rates of training in herd health management were also significantly higher for participants 41 years of age and younger. These findings are 


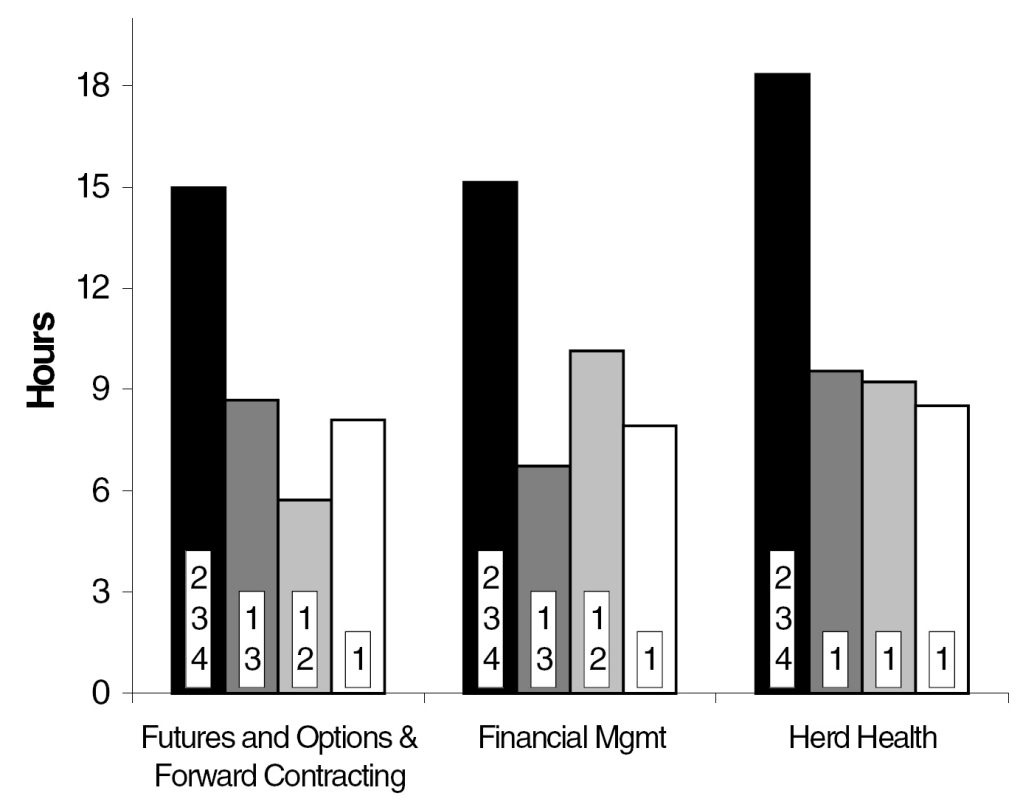

Age $<41 \square$ Age 41-50 $\square$ Age 51-60 $\square$ Age > 60

Figure 7. Hours of attendance by beef producers at educational seminars

(Numbers in boxes represent pairwise relationships that are significant across the indicated strata)

consistent with the hypothesis of the Ben-Porath model; younger producers invest more of their time in continuing education because of the longer remaining time horizon for benefits to accrue.

There was no significant difference between any paired age strata of attendance at financial management educational programs. One possible explanation is that while young producers are interested in training to support effective management of financial risk while they are building wealth, older producers show equal interest in effectively managing the substantial wealth they have already accumulated.

The average number of hours of educational program training completed by survey participants (Figure 7) shows a trend similar to that for participation rates. Producers in the youngest age stratum attended significantly more hours of training (15.0 hours on average) than other age strata (overall average of 8.3 hours) for all three educational program categories. No consistent pattern of participation is found among producers in the older three age strata.

In agreement with the Ben-Porath model, producers in the youngest age stratum attended more than double the number of hours of risk management educational programs compared with producers in other strata. Two important messages to policy formulators and educators are clear. First, target the majority of resources to programs designed for younger persons who are more likely to attend. Second, to increase attendance of older age groups, the types of risk management tools discussed may need to be modified given the current evidence of low historical levels of interest. 
Table 1. Definition of variables used in probit models of beef producers' strong interest in additional risk management education

\begin{tabular}{|c|c|}
\hline Variable & Description \\
\hline $\begin{array}{l}\text { Producer's preference for } \\
\text { further risk management } \\
\text { education }\end{array}$ & $\begin{array}{l}\text { Dependent variable indicating producers responded } \\
\text { with a } 4 \text { or } 5 \text { on a } 1-5 \text { scale when asked to rank their } \\
\text { preference for further risk management education in } \\
\text { each of four areas; } 1=\text { low interest, } 5=\text { strong interest. }\end{array}$ \\
\hline Age & Age of the primary farm operator \\
\hline Previous attendance & $\begin{array}{l}\text { Dummy variable indicating that the operator attended an } \\
\text { educational program in the last } 3 \text { years to learn more } \\
\text { about using the particular risk management practice }\end{array}$ \\
\hline Prior use & $\begin{array}{l}\text { Dummy variable indicating that the risk management } \\
\text { practice was a strategy used in the last } 3 \text { years }\end{array}$ \\
\hline Risk aversion & $\begin{array}{l}\text { Dummy variable indicating that the operator responded } \\
\text { with a } 4 \text { or } 5 \text { on a } 1-5 \text { scale when asked if the primary } \\
\text { goal is to reduce risk, rather than raise price; } 1=\text { not at } \\
\text { all willing, } 5 \text { = very willing }\end{array}$ \\
\hline Knowledgeable in subject & $\begin{array}{l}\text { Dummy variable indicating that the operator responded } \\
\text { with a } 4 \text { or } 5 \text { on a } 1-5 \text { scale when asked about } \\
\text { knowledge of the management tool; } 1=\text { not at all } \\
\text { knowledgeable, } 5=\text { very knowledgeable }\end{array}$ \\
\hline Total acres & $\begin{array}{l}\text { Total acres in the ranching/farming operation that are } \\
\text { owned, rented, or managed for someone else }\end{array}$ \\
\hline Total head & Total head of cattle (cows + stockers + feeders) \\
\hline Cows/stockers: proportion & $\begin{array}{l}\text { Variables indicating the proportion of total head of cattle } \\
\text { of total head that are cows or stockers }\end{array}$ \\
\hline $\begin{array}{l}\text { Percent of gross income } \\
\text { from beef production }\end{array}$ & $\begin{array}{l}\text { Percentage reported by the operator of the ranch/farm } \\
\text { gross that is expected to come from beef production }\end{array}$ \\
\hline
\end{tabular}

\section{Modeling Desire for Further Education}

A set of variables was hypothesized to be important in explaining producers' decisions to obtain further education. These variables were used to estimate the probit models of desire for additional education, described below. Tables 1 and 2 describe and summarize the variables identified.

\section{Data Preparation and Description of Variables}

Data from the questionnaire were used to model producers' preferences for additional information or education on risk management tools. Binary dependent variables were constructed to indicate producers' strong interest in obtaining additional education in each of four risk management tools (forward contracting, futures and options, financial management, and herd health management), based on producers' answers to relevant questions on the questionnaire. ${ }^{5}$

Age, previous attendance at educational programs, and prior use of risk management strategies are all consistent with the Ben-Porath model described earlier. Age is hypothesized to be the most important determinant of the model; previous 
Table 2. Summary statistics of variables used in probit models of beef producers' strong interest in additional risk management education

\begin{tabular}{lcr}
\hline Variable & Mean & Std. Dev. \\
\hline Interest in further education & & \\
$\quad$ Forward contracts & 0.23 & 0.42 \\
Futures and options & 0.26 & 0.44 \\
$\quad$ Financial management & 0.38 & 0.49 \\
Herd health & 0.57 & 0.49 \\
Demographic characteristics & 57.31 & 13.18 \\
Age & & \\
Previous Attendance & 0.16 & 0.37 \\
$\quad$ Forward contracts/Futures and options & 0.38 & 0.48 \\
$\quad$ Financial management & 0.16 & 0.36 \\
$\quad$ Herd health & & \\
Prior use of risk management strategy & 0.05 & 0.21 \\
$\quad$ Forward contracts & 0.07 & 0.26 \\
$\quad$ Futures and options & 0.10 & 0.30 \\
$\quad$ Financial management & 0.90 & 0.30 \\
$\quad$ Herd health & 0.32 & 0.47 \\
$\quad$ Risk aversion & & \\
Knowledge in subject & 0.11 & 0.31 \\
$\quad$ Forward contracts & 0.12 & 0.33 \\
$\quad$ Futures and options & 0.33 & 0.47 \\
$\quad$ Financial management & 0.53 & 0.50 \\
$\quad$ Herd health & & \\
Farm characteristics & $2,429.64$ & $9,238.01$ \\
Total acres & 282.45 & $1,675.29$ \\
Total head & 0.78 & 0.32 \\
Cows: proportion of total head & 0.17 & 0.28 \\
Stockers: proportion of total head & 60.50 & 35.21 \\
Percent of gross income from beef production & & \\
\hline
\end{tabular}

${ }^{a}$ Mean values between 0 and 1 indicate proportion of producers (e.g., 23\% of producers responding indicated strong interest in forward contracts, and 16\% previously attended herd health training).

attendance at educational programs is an indicator of past interest in human capital investment; prior use of the risk management strategy in question captures an element of experience.

Producers were questioned regarding their attitudes to risk aversion in order to construct a risk-aversion variable for the probit models. Those producers who believe risk has high potential to affect their income are assumed to be more likely to pursue risk management education to reduce those risks. Respondents were also asked to assess their level of knowledge of the risk management instrument of interest using a Likert 5-point scale (knowledge in subject).

Other explanatory variables included characteristics of the enterprise: total acres, total head, proportion of cattle that are cows, proportion of cattle that are stockers, and the percent of gross income that is derived from beef production. 
Fifty-seven percent of respondents expressed a strong interest in additional information or education for herd health management (table 2). Fewer respondents expressed strong interest in financial management education (38\%). Approximately $25 \%$ of respondents expressed strong interest in additional information on forward contracts or futures and options, less than half that for herd health management education.

Fewer than $10 \%$ of respondents' for each category reported prior use (Table 2) of risk management strategies other than herd health; $90 \%$ indicated prior use of herd health management. It is not surprising that herd health use is pervasive, as most producers vaccinate or deworm their cattle (National Animal Health Monitoring System, $1997 \mathrm{~b}, \mathrm{pp} .4-8)$. It is remarkable, however, that only $10 \%$ of producers claim some experience in the last three years with financial management, a risk management tool that most extension economists consider essential to proper farm business management (Kay and Edwards). The low use of futures and options or forward contracts was not unexpected and is in agreement with previous findings (National Animal Health Monitoring System, 1997a, pp. 25-31).

\section{Probit Model Results}

This section describes the results of modeling beef producers' stated strong interest in obtaining additional education in each of four risk management tools (forward contracting, futures and options, financial management, and herd health management). Probit models of the independent variables described were estimated using a standard maximum likelihood approach (Greene; Maddala). Table 3 presents estimates of the parameter values and the marginal effects.

Operator age, previous attendance, and prior use of the management tool are strong indicators $(p=0.10)$ of desire for additional risk management education for all four risk management tools. These are the most important variables of the model in terms of predicting which beef cattle producers express desire for further risk management educational training, and each will be considered in turn.

Operator age has a negative effect, as expected, and as observed by other researchers working with crops (Goodwin and Schroeder, Knight et al.). As beef producers become older, the marginal benefit they expect to derive from attending one additional hour of education decreases; their investment in human capital is a declining function of age. This is summarized in the marginal values for age, which tell us that the probability of participation in forward contracting, futures and options, and financial management falls by $0.56 \%, 0.64 \%$, and $0.69 \%$, respectively, for every additional year of age. The effect of age on the likelihood of stating strong preference in herd health education is less pronounced $(0.25 \%)$. Thus, a beef producer who is 55 years old is about $13.8 \%$ less likely $(-0.69 \%$ times 20 years) to express strong interest in attending additional risk management education in financial management than a beef producer who is 35 . These values represent the mean ages in stratum 1 and 3, respectively. Similarly derived values for forward contracting, futures and options, and herd health are $11.2 \%, 12.8 \%$, and $5.0 \%$, respectively.

Clearly these results indicate that age is strongly associated with stated preference in further education in risk management. The implications of this have been discussed previously; these results show that for beef producers, the effect is significant and nontrivial in magnitude. 


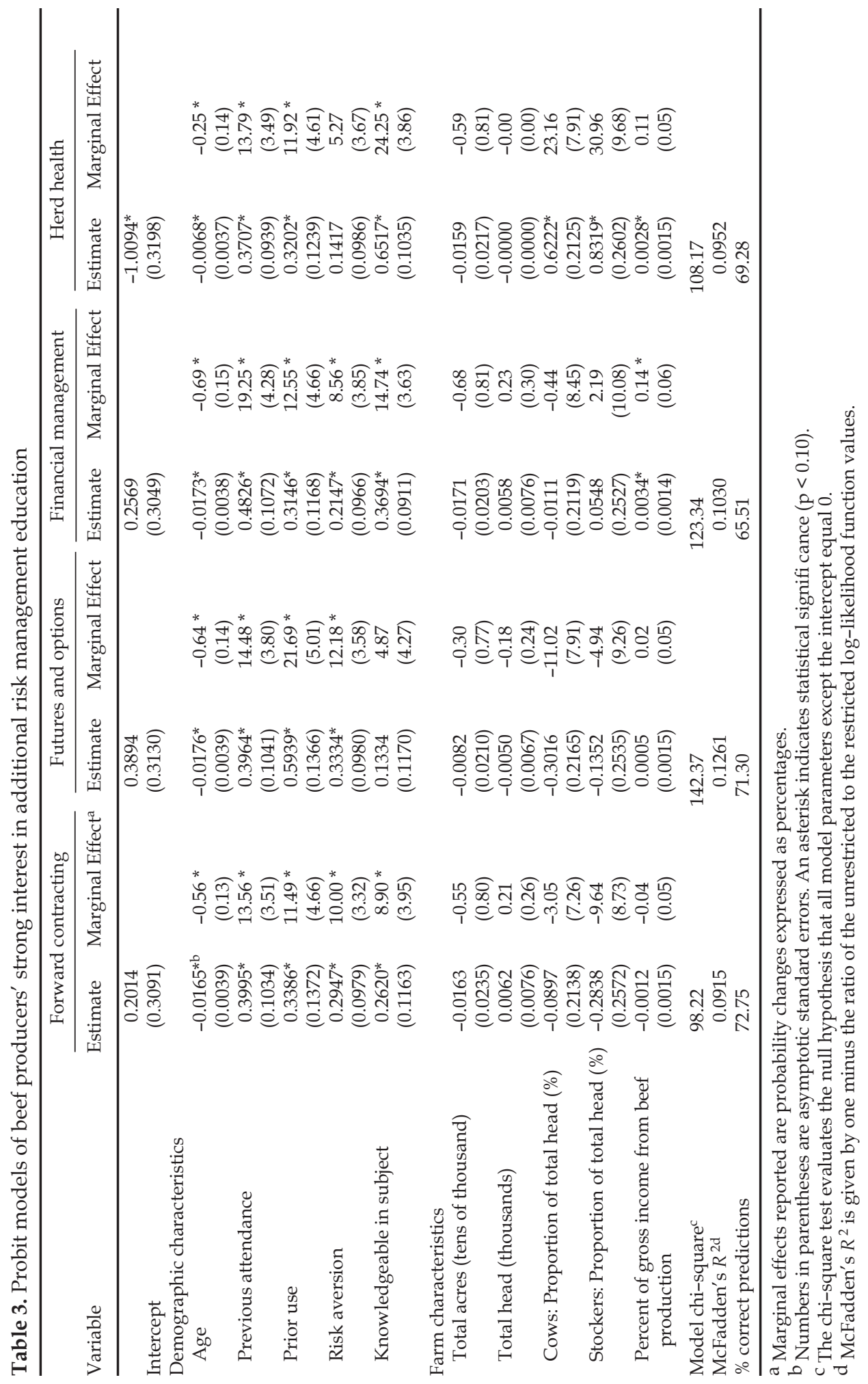


Recalling that beef producer attendance at risk management educational seminars is low for many categories (Figure 6), the probit model results gives quantitative results of the link between past attendance and future interest. Previous attendance has a positive effect on the probability of respondents expressing strong interest in additional risk management educational programs. The probability that beef cattle producers express strong interest in attending additional risk management educational programs in financial management, for example, increases by more than $19 \%$ if they have attended educational programs previously. In the case of futures and options, forward contracting, and herd health risk management, the effects are nearly as large, at roughly $14 \%$ each.

This is an important finding and has relevance to the planning of future programs. While beef producers with no past attendance are less likely to be interested in risk management programs, it should not be misconstrued that programs should only be targeted at previous attendees. It does suggest that those individuals who have not attended might require additional or alternate program features to enroll. Certainly these are findings that warrant further attention.

The estimated effect of prior use of a specific risk management tool on the probability of stating strong interest in additional education is positive in all models. If beef producers recently used futures and options, the probability of expressing strong interest in attending additional training increases by $22 \%$. Similarly, recent prior use of financial management and forward contracting increases the likelihood that beef producers will attend additional training by $13 \%$ and $11 \%$, respectively. Likewise, recent herd health use increases the likelihood of expressing a strong desire for additional training by $12 \%$. This finding is important to planners of risk management educational programs for beef producers. It indicates that those beef producers who have recently used a risk management tool are significantly more likely to want further training. The corollary is that such programs will be harder to market to beef producers with no prior experience in their use.

Beef cattle producers who respond they are more risk averse are significantly more likely to state strong preference for further education in three of the four risk management options. Not surprisingly, the price management tools (forward contracting and futures and options) exhibited the strongest marginal effects. Risk averse producers were 10\% and 12\% more likely to express strong interest in attending additional training in forward contracting and futures and options, respectively. Beef producers were nearly $9 \%$ more likely to express strong interest in attending further education in financial management if they felt they were risk averse. It is likely that beef producers feel that financial management, which does not provide direct protection from price risk, is of less value under circumstances of beef cattle price variability. Risk aversion was not a significant determinant for the likelihood of expressed interest in herd health training.

Self assessment of knowledge had large positive and significant impact on the likelihood that beef producers would express desire for further risk management education in forward contracting, financial management, and herd health. Producers' with a high self-assessment of their knowledge in forward contracting, financial management, and herd health are significantly more likely to be interested in further education in those skills. The largest magnitude of effect was for herd health risk management education, where producers who felt they were knowledgeable in herd health management were $24 \%$ more likely to express a strong 
interest in attending further herd health management education. In other words, those beef producers who feel they are less knowledgeable in herd health are significantly less likely to express interest in further education. We believe there may well be some beef cattle producers in this category who are open-minded about further education but are perhaps intimidated by their perceived lack of knowledge in herd health. Further analysis of this finding is warranted.

Total acres and head of cattle were not significant at the $10 \%$ level in any model. This unexpected result suggests that stated interest in attending risk management programs is not affected by the size of the operation as measured by acreage or number of cattle. The proportion of cows and stockers, however, significantly affected expressed interest in further risk management education in the herd health model. For beef cattle producers specializing in cow-calf or stocker operations, there is a $23 \%$ and $31 \%$, respectively, increased likelihood of expressing strong interest in herd health management education compared with those specializing in feeder cattle. This would seem to justify tailoring some herd health programs to suit the specific needs of these two groups of beef cattle producers. Higher-income producers (who are possibly more specialized producers in that percent of income from beef cattle is more likely to indicate specialization) tend to be significantly more likely to express interest in further education in financial management and herd health risk management education.

These last results on total acres and head of cattle suggest that the objective variables one traditionally associates with larger, more progressive operations are not necessarily good indicators of expressed interest in additional education in risk management. Parallels exist between these findings and the results of at least one other study. Pompelli et al., modeling preferences for soil conservation information, observed that farm size and gross sales were not significant predictors of operator decisions to seek further education. Previous studies have found farm size or farm income to be significant in predicting interest in education (Goodwin and Schroeder) or adoption (Davis and Patrick, Newbery and Stiglitz, Shapiro and Brorsen). Other studies have yielded mixed results (Knight et al.). ${ }^{6}$ If nothing else, these conflicting results emphasize the complexity of identifying accurate predictors of farmers' decision making processes.

\section{Conclusions}

It is not clear from the current literature how livestock producers manage not just price but also production risk, how they view different sources of risk, and their interest in obtaining further education in risk management techniques. This study contributes to the literature by addressing these issues for beef cattle producers: Most importantly, it provides the first analysis and modeling of the educational demands of beef cattle producers for additional educational programs in risk management, based on the results of an in-depth, large-scale survey.

Several variables were identified as important in distinguishing producers who might express a strong desire for further risk management educational training. Age, prior use of risk management tools, previous risk management education, and to a lesser extent, risk aversion were significant predictors of producers' strong interest in additional educational training. These variables coincide with 
the Ben-Porath model of human capital investment, and should provide policy makers with advice for targeting the development of further risk management tools and educational programs and materials.

Severe drought and cattle price variability were identified as perceived by beef cattle producers in Texas and Nebraska as primary risk factors with potential to affect farm income. Extremely cold weather and disease were identified as less important. Producers appear to be consistent with these beliefs in their perceptions of the efficacy of drought and cold weather management strategies; understocking pasture and storing hay were perceived most effective as risk management strategies.

The picture that emerges with respect to price risk management is less consistent. When asked their primary reason for not using futures and options, 51\% of producers reported that they did not have enough knowledge. Yet only half that number expressed strong interest in obtaining further education in futures and options. This may account for the very low ranking of forward contracting and futures and options in producers' perceptions of risk management strategies with potential to affect farm income. To be fair, the confusion may lie with interpretation of the findings. Many of the producers who express low knowledge in futures and options may have no interest in acquiring further risk management education of any kind. These points raise questions regarding identification of appropriate risk management programs, relevant target audiences, differentiation of knowledge of risk management tools from knowledge of markets, and suitability of signaling variables from producers. This is an area that deserves more attention from risk management researchers.

There are other questions that this study raises that should be considered by researchers of livestock risk management. For example, what tools are provided or could be developed by adult education specialists to encourage more interest from older producers in risk management educational programs? What areas of livestock production or price risk management are most appropriate to what areas of the country and what age groups would be most responsive to pertinent educational programs? If expansion of producer knowledge relevant to the reduction of the impact of specific risk factors associated with livestock production is desirable, what are the appropriate variables to measure this desire for education?

This study finds agreement with Patrick and DeVuyst and with Selley and Wilson in identifying a need for more work in applied risk analysis and in developing risk management tools or education programs. The U.S. Congress has addressed one of the concerns expressed by Selley and Wilson in identifying funds for pilot risk management programs, and for livestock producers in particular. We have examined beef cattle producers' perceptions of sources of risk and the effectiveness of risk management strategies, and their stated interest in obtaining further risk management information. The results presented should provide a solid starting point from which to identify key indicator variables useful in developing risk management tools and educational programs for beef cattle producers.

\section{Acknowledgments}

The authors are grateful to Ms. Sammye Crawford, National Agricultural Statistics Service, Austin, Texas for her expert assistance with data preparation. 


\section{Endnotes}

1. Although some information on price risk management is available in the literature, there is little previous work in assessing livestock producers' use of production risk management tools. Boggess, Anaman, and Hanson surveyed 48 producers in Florida and Alabama and reported that relative to crops, livestock risks were seen as less important, although for livestock farmers certain risks including weather and disease were seen as highly important. Patrick et al. also surveyed 28 livestock producers in 12 states and reported that livestock prices and weather were primary sources of concern. Since livestock production risk management is thinly covered in the literature, this study emphasized that perspective of livestock risk management.

2. From the "Agriculture Risk Protection Act Of 2000," Public Law 106-224, 106th Congress. Sec. 132. Pilot Programs:

(10) Limitation on expenditures. - The Corporation shall conduct all livestock programs under this title so that, to the maximum extent practicable, all costs associated with conducting the livestock programs (other than research and development costs covered by section 522) are not expected to exceed the following: (A) $\$ 10,000,000$ for each of fiscal years 2001 and 2002. (B) $\$ 15,000,000$ for fiscal year 2003. (C) $\$ 20,000,000$ for fiscal year 2004 and each subsequent fiscal year.

3. Producer education and interest in continuing education have been important elements of extension education for U.S. producers. Knight et al. provide a concise history of risk management education, including reference to the important early work conducted by Walker and Nelson.

4. This is an additional volume of hay that is being stored to offset the impact of drought, should it occur.

5. The binary dependent choice variables were created by condensing multinomial choice variables that ranged from 0 to 5 . Questionnaire responses that ranged from 0 to 3 were converted to a 0 representing, for example, "low to moderate interest," and responses of 4 or 5 were converted similarly to a 1 representing "high interest." We feel that the amount of information lost, if any, was outweighed by the benefits of this process for the following reasons. These choice variables are subjective in nature (e.g., stated preference for attending a herd health seminar) rather than objective (e.g., transportation mode), making interpretation of small differences in responses difficult between respondents. Using a condensed binomial variable reduces this confusion of interpretation of subjective responses. It also provides the reader with a less complicated range of interpretations of minor degree of the reported choices made by the respondents from this large sample. Importantly, our results are robust in the binomial. When we created the binomial variables using slightly different definitions (in the binomial variable a 0 represented a questionnaire response of 0 to 2, and a 1 represented a response of 3 to 5), the results of the model were consistent with those reported.

6. Farm size was significant in modeling stated strong interest in additional risk management education for revenue insurance and financial management, but not for forward contracting, futures and options, or yield insurance.

\section{References}

Barry, P.J. "The Setting." In: Risk Management in Agriculture. Ames, IA: Iowa State University Press, 1984.

Ben-Porath, Y. “The Production of Human Capital and the Life Cycle of Earnings." J. Political Econ. 75(August 1967):352-65.

Boggess, W.G., K. A. Anaman, and G.D. Hanson. “Importance, Causes, and Management Responses to Farm Risks: Evidence from Florida and Alabama." South. J. Agr. Econ. 17(December 1985):105-16.

Carpenter, B.B. and C.R. Hart. Livestock Management during Drought. College Station, TX: Texas Agricultural Extension Service, Texas A\&M University, RLEM No. 2, 1999.

Davis, T.D. and G.F. Patrick. "Do Producer Risk Attitudes Affect the Sizing of the On-Farm Harvest, Drying, and Storage System?" Cdn. J. Agr. Econ. 50(March 2002):1-14.

Gardner, G., and R. Likert. Public Opinion and the Individual: A Psychological Study of Student Attitudes on Public Questions, with a Retest Five Years Later. New York: Harper, 1938.

Goodwin, B.K. "An Empirical Analysis of the Demand for Multiple Peril Crop Insurance." Amer. J. Agr. Econ. 75(May 1993):425-34 
Goodwin, B.K. and T.C. Schroeder. "Human Capital, Producer Education Programs, and the Adoption of Forward-Pricing Methods." Amer. J. Agr. Econ. 76(November 1994):936-47.

Greene, W. Econometric Analysis, 4th ed. New York: Prentice Hall, 2000.

Guyer, P.Q. Retaining Ownership of Calves or Yearlings. Lincoln, NE: Cooperative Extension, Institute of Agriculture and Natural Resources, University of Nebraska, NebGuide G85-766-A, 1996.

Hardaker, J.B., R.B.M. Huirne, and J.R. Anderson. "Introduction to Risk in Agriculture," In: Coping with Risk in Agriculture. New York: CAB International, 1997.

Hart, C.R., and B.B. Carpenter. Stocking Rate and Grazing Management during Drought. College Station, TX: Texas Agricultural Extension Service, Texas A\&M University, RLEM No. 4, 1999.

Kay, R.D., and W.M. Edwards. Farm Management. Boston, MA: McGraw-Hill, 1999.

Knight, T.O., and K.H. Coble. "Survey of the U.S. Multiple Peril Crop Insurance Literature Since 1980." Rev. of Agr. Econ. 19(Spring/Summer 1997):128-56.

Knight, T.O., K.H. Coble, G.F. Patrick, and A.E. Baquet. “Risk Management Education: Guidance for Future Programs." Unpublished manuscript, Texas A\&M University, College Station, TX, 2000.

Lawrence, J.D., and Z. Wang. Alternative Cow Herd Inventory Strategies: Constant Size And Constant Investment. Iowa State A.S. Leaflet 1338, 1995.

Likert, R. “A Technique for the Measurement of Attitudes.” Arch. Psychol. 140(June 1932):55.

Maddala, G.S. Limited-Dependent and Qualitative Variables in Econometrics. New York: Cambridge University Press, 1983.

Mahul, O. “Optimum Area Yield Crop Insurance." Amer. J. Agr. Econ. 81(February 1999):75-82.

National Animal Health Monitoring System. Beef'97. Part I: Reference of 1997 Beef Cow-Calf Management Practices. Washington DC: NAHMS-APHIS-USDA, 1997a.

- Beef'97. Part II: Reference of 1997 Beef Cow-Calf Health and Health Management Practices. Washington DC: NAHMS-APHIS-USDA, 1997b.

- Beef '97. Part II: Reference of 1997 Beef Cow-Calf Production Management and Disease Control. Washington DC: NAHMS-APHIS-USDA, 1997c.

Newbery, D.M.G., and J. Stiglitz. The Theory of Commodity Price Stabilization. Oxford, UK: Clarendon Press, 1981, Chapters 12-13.

Patrick, G.F., and E.A. DeVuyst. "Whence and Whither in Farm Management Risk Research and Extension Delivery." Can. J. Agr. Econ. 43(March 1995):1-21.

Patrick, G.F., W.N. Musser, and D.T. Eckman. "Forward Marketing Practices and Attitudes of LargeScale Midwestern Grain Producers.” Rev. Agr. Econ. 20(Spring/Summer 1998):38-53.

Patrick, G.F., P.N. Wilson, P.J. Barry, W.G. Boggess, and D.L. Young. "Risk Perceptions and Management Responses: Producer-Generated Hypotheses for Risk Modeling." South. J. Agr. Econ. 17(December 1985):231-38.

Pompelli, G., C. Morfaw, B.C. English, R.G. Bowling, G.S. Bullen, and F. Tegegne. "Farm Operators' Preferences for Soil Conservation Service Information: Results from Three Tennessee Watersheds." J. Prodn. Agr. 10(July-September 1997):472-76.

Radostits, O.M., K.E. Leslie, and J. Fetrow. Herd Health: Food Animal Production Medicine. Toronto, Canada: W.B. Saunders, Co., 1994.

Rowan, R.C., L.D. White, and J.R. Conner. "Understanding Cause/Effect Relationships in Stocking Rate Change Over Time." J. Range Mgt. 47(September 1994):349-54.

Schroeder, T.C., C.E. Ward, J.R. Mintert, and D.S. Peel. "Value-Based Pricing of Fed Cattle: Challenges and Research Agenda." Rev. Agr. Econ. 20(Spring/Summer 1998):125-34.

Selley, R.A., and P.N. Wilson. "Risk Research and Public Outreach: Tale of Two Cultures?" J. Agr. Res. Econ. 22(December 1997):222-32.

Shapiro, B.I., and P.W. Brorsen. "Factors Affecting Farmers' Hedging Decisions." N. C. J. Agr. Econ. 10(July 1988):145-53.

U.S. Congress. “H.R. 2559-The Agricultural Risk Protection Act of 2000.” Washington D.C., 2000.

Walker, O.L., and A.G. Nelson. Agricultural Research and Education Related to Decision-Making under Uncertainty: An Interpretive Review of the Literature. Stillwater, OK: Oklahoma Agricultural Experiment Station, Oklahoma State University, Research Report P-747, March 1977.

Ward, C.E., D.M. Feuz, and T.C. Schroeder. Formula Pricing and Grid Pricing Fed Cattle: Implications for Price Discovery and Variability. Stillwater, OK: Department of Agricultural and Applied Economics, Oklahoma State University, Research Bulletin 1-99, January 1999.

White, L.D., and T.R. Troxel. Balancing Forage Demand with Supply. College Station, TX: Texas Agricultural Extension Service, Texas A\&M University, Bulletin B-1606, 1999. 